\title{
Analysis of asset risk and household Financial Asset Allocation structure----Empirical analysis from a nonlinear model
}

\author{
Zhanbing Huang ${ }^{1, a}, \mathrm{Yu} \mathrm{Lu}^{1, \mathrm{~b}}$ \\ ${ }^{1}$ International Business School, Shaanxi Normal University, Xi'an, China
}

\begin{abstract}
Chinese households now have a good understanding of finance and their asset allocation choices are increasingly skewed towards financial products. At present, most domestic and foreign researches on the structure and choice of household asset allocation mainly analyze the influence of residents' characteristics or financial literacy on household asset allocation, while few researches on the internal relationship between household risk, asset structure and allocation choice. Based on CHFS data and the theory of asset investment behavior, this paper systematically analyzes and risk assets and family financial asset allocation structure of mutual influence and role, an empirical analysis of the influencing factors of residents in our country family financial asset allocation structure by using Probit model and Tobit model, pay attention to risk assets, family income and other factors, a deeper understanding of family financial asset investment circumstances.
\end{abstract}

\section{Introduction}

As a microeconomic unit of the society, households' asset allocation directly affects the scale and structure of the capital market and the development and innovation degree of the financial industry. In recent years, there are more and more researches on the family as the investment subject, which can be roughly divided into two categories. One is to analyze the micro individual factors, such as risk preference and education level. The other is the macroscopic external environmental factors. The relationship between the degree of household access to the financial market and its asset portfolio is studied more abroad.

\section{Theory and Model of household financial asset allocation structure}

Family financial asset allocation is essentially a family themed asset portfolio problem. Asset portfolio theory is also based on two indicators: profitability and risk of assets. Among them, the profitability index of assets can be measured by expected rate of return, while the risk of assets can be measured by standard deviation or variance. There is a correlation between the returns and risks of various assets. As long as the returns and risks of assets are given, then the investment portfolio of investors will be determined. Therefore, when investors make investment decisions, they can use diversified portfolios to diversify risks and maximize the utility of assets. In fact, the asset selection behavior of investors is very complex, which should not be studied in a perfect market, but in an incomplete market based on its theoretical and empirical research. This paper discusses the asset allocation management from the perspective of the risk of the family in which the investor lives, which can better explain his investment behavior.

Considering that the explained variables in this paper are whether the family enters the stock market, the degree to which the family enters the stock market and the risk financial asset market respectively, the former is a discrete variable, while the latter may involve 0 . The following models are used for empirical analysis.

When studying the impact of asset risk on family's entry into the stock market, the empirical analysis model (Probit model) equation is as in (1):

$$
y_{i}^{*}=x \beta+u_{i}^{*}
$$

$y_{i}^{*}$ is the potential variable that cannot be observed, $\mathrm{x}$ is the explanatory variable, and the observable dummy variable $y_{i}$, which satisfies the following relation as in (2):

$$
y_{i}=\left\{\begin{array}{l}
1, \text { if } y_{i}^{*}>0 \\
0, \text { if } y_{i}^{*} \leq 0
\end{array}\right.
$$

When studying the impact of asset risks on households' access to the stock market and the degree of risky financial assets market, the empirical model (Tobit model) equation is as in (3):

$$
y_{i}^{*}=x \beta+u_{i}^{*}
$$

$y_{i}^{*}$ is the potential variable that cannot be observed, $\mathrm{x}$ is the explanatory variable, and the observable dummy variable $y_{f}$, which satisfies the following relation as in (4):

$$
y_{f}=\left\{\begin{array}{c}
y_{i}^{*}, \text { if } y_{i}^{*}>0 \\
0, \text { if } y_{i}^{*} \leq 0
\end{array}\right.
$$




\section{General situation of financial asset allocation structure of Chinese households}

In this paper, data from southwest university of finance and China family financial investigation items (CHFS). The main research object is the risk of family assets and the allocation of family financial assets. Therefore, before setting the analysis model, the overall situation of family assets, the risk of family assets and the allocation and management of family financial assets are analyzed and described.

\subsection{Household asset allocation structure}

TABLE I. Total Assets and Liabilities of households by Region (unit: yuan)

\begin{tabular}{|c|c|c|c|c|c|}
\hline $\begin{array}{c}\text { Distributio } \\
\boldsymbol{n} \text { area }\end{array}$ & $\begin{array}{c}\text { Total } \\
\text { assets }\end{array}$ & $\begin{array}{c}\text { Total } \\
\text { liabilities }\end{array}$ & $\begin{array}{c}\text { Net } \\
\text { worth }\end{array}$ & $\begin{array}{c}\text { Financial } \\
\text { assets }\end{array}$ & $\begin{array}{c}\text { Non- } \\
\text { financial } \\
\text { assets }\end{array}$ \\
\hline $\begin{array}{c}\text { The eastern } \\
\text { family }\end{array}$ & 780188.1 & 903.7733 & 779284 & 49725.13 & 730463.050 \\
\hline $\begin{array}{c}\text { The } \\
\text { western } \\
\text { family }\end{array}$ & 778666.0 & 845.2496 & 777820 & 46639.51 & 732026.525 \\
\hline $\begin{array}{c}\text { The central } \\
\text { family }\end{array}$ & 800351.2 & 877.0857 & 799474 & 49070.01 & 751281.182 \\
\hline $\begin{array}{c}\text { All the } \\
\text { family }\end{array}$ & 785989.7 & 822.0579 & 785107 & 48809.73 & 737180.036 \\
8
\end{tabular}

According to TABLE I, in general, the average total assets of all Chinese families are 785989.7741 yuan, the total liabilities are 822.0579 yuan, and the net assets are 785107.7162 yuan, among which the financial assets are 48809.7373 yuan and the non-financial assets are 737180.0368 yuan. The financial asset allocation in all regions is almost the same. However, the level of family assets in central China is higher than that in eastern and western China, but the difference is not large.

\subsection{Household financial asset allocation}

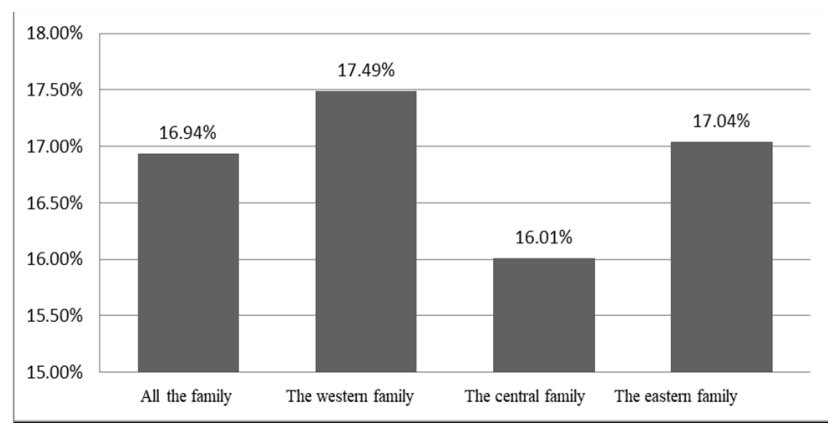

Fig1. Household stock asset allocation ratio

It can be seen from Fig. 1 that the proportion of stock assets in Chinese households' financial assets is moderate, not less than $10 \%$, indicating that Chinese households have improved their understanding of the stock market and are willing to accept and invest in the stock market. Among them, the eastern part of the family of the proportion between the three is the highest, $17.49 \%$, three in proportion.

\subsection{Asset risk}

In this paper, the standard deviation is used to measure the risk of household financial assets. Deposit financial assets have the lowest return and risk, while stock financial assets have the highest return and risk. It can be seen from Table II.

TABLE II. Historical return on assets and risk

\begin{tabular}{|c|c|c|}
\hline Kinds & The yield & standard deviation \\
\hline Deposit financial assets & $2.0 \%$ & $0.0 \%$ \\
\hline Bond financial assets & $3.8 \%$ & $2.3 \%$ \\
\hline Equity financial assets & $12.6 \%$ & $29.2 \%$ \\
\hline
\end{tabular}

This paper is divided into three categories: Low risk assets, Asset risk in medium and Risky assets.

TABLE III. Historical return on assets and risk

\begin{tabular}{|c|c|c|c|c|}
\hline Kinds & $\begin{array}{c}\text { All the } \\
\text { family }\end{array}$ & $\begin{array}{c}\text { Low risk } \\
\text { assets }\end{array}$ & $\begin{array}{c}\text { Asset risk } \\
\text { in medium }\end{array}$ & $\begin{array}{c}\text { Risky } \\
\text { assets }\end{array}$ \\
\hline $\begin{array}{c}\text { Number of } \\
\text { families by type }\end{array}$ & 28142 & 4537 & 22205 & 1400 \\
\hline $\begin{array}{c}\text { The number of } \\
\text { households with } \\
\text { stock accounts }\end{array}$ & 2220 & 491 & 357 & 1372 \\
\hline $\begin{array}{c}\text { Participation } \\
\text { ratio of stock } \\
\text { Market }\end{array}$ & $7.89 \%$ & $10.82 \%$ & $1.61 \%$ & $98 \%$ \\
\hline $\begin{array}{c}\text { The proportion } \\
\text { of stock assets }\end{array}$ & $16.94 \%$ & $3.32 \%$ & $2.98 \%$ & $56.06 \%$ \\
\hline $\begin{array}{c}\text { The proportion } \\
\text { of risky financial } \\
\text { assets }\end{array}$ & $31.92 \%$ & $13.86 \%$ & $17.74 \%$ & $76.28 \%$ \\
\hline
\end{tabular}

As can be seen from TABLE III, Chinese families have improved their concept of asset allocation. There are more or less risky financial assets in family assets, and the risks brought by investment can be properly avoided in investment. Meanwhile, there are a total of 2220 families participating in the stock market, accounting for $7.89 \%$ of the total sample size. The participation rate of families with relatively high asset risks in the stock market is also relatively high. At present, China needs to guide more investment in the stock market when formulating relevant policies, so that Chinese residents can understand the stock market in all aspects and increase their participation in the stock market.

\section{The empirical results}

\subsection{Variable selection}

The explained variables are whether households enter the stock market, the degree of households entering the stock market and the risk financial asset market. The explanatory variable is the asset risk.

TABLE IV. Descriptive statistics of variables

\begin{tabular}{|c|c|c|c|}
\hline Variable & Obs & Mean & Std. Dev. \\
\hline Hold & 26,664 & .7268161 & 35.84323 \\
\hline holdratio & 26,664 & .7268161 & 35.84323 \\
\hline
\end{tabular}




\begin{tabular}{|c|c|c|c|}
\hline ratio & 26,664 & .0645725 & .2092846 \\
\hline risk1 & 28,140 & .0497512 & .2174344 \\
\hline risk2 & 28,140 & .1612296 & .3677491 \\
\hline income & 28,140 & 63414.4 & 141356.6 \\
\hline asset & 28,140 & 785163.2 & 1581142 \\
\hline age & 28,140 & 48.60362 & 33.48598 \\
\hline edu & 25,013 & 2.124655 & 1.366264 \\
\hline marry & 22,389 & .8497476 & .3573266 \\
\hline gender & 28,140 & .4989694 & .5000078 \\
\hline east & 28,140 & .4629353 & .4986332 \\
\hline west & 28,140 & .2318763 & .4220379 \\
\hline area & 28,140 & .3174129 & .4654779 \\
\hline estate & 21,594 & .8821895 & .3223911 \\
\hline number & 28,138 & 3.479316 & 1.627788 \\
\hline
\end{tabular}

It can be seen from TABLE IV that Chinese families gradually get rid of the concept of conservative family investment and gradually enter the ideal investment state. It shows that the most of the families in China focus on the safety of financial assets, it held by the family take some less risk in financial assets. And we can see that most householders have only high school education or less, with the majority having secondary school education.

\subsection{Regression analysis}

TABLE V. Asset risk participates in regression analysis of stock market

\begin{tabular}{|c|c|c|c|}
\hline Variable & coefficient & $\boldsymbol{t}$ & $\boldsymbol{P}$ values \\
\hline risk1 & $3.863794^{* * *}$ & 35.08 & 0.000 \\
\hline risk2 & $.6600495^{* * *}$ & 13.20 & 0.000 \\
\hline lnincome & $.1444847^{* * *}$ & 5.75 & 0.000 \\
\hline lnasset & $.321746^{* * *}$ & 12.75 & 0.000 \\
\hline age & -.0000128 & -0.02 & 0.986 \\
\hline edu & $.0626658^{* * *}$ & 4.21 & 0.000 \\
\hline marry & .0108629 & 0.15 & 0.881 \\
\hline gender & $-.1071945^{* *}$ & -2.23 & 0.026 \\
\hline east & -.0424537 & -0.75 & 0.450 \\
\hline west & .0138381 & 0.21 & 0.832 \\
\hline area & .0161872 & 0.31 & 0.758 \\
\hline estate & $-.6190791 * * *$ & -6.61 & 0.000 \\
\hline number & $-.075273^{* * *}$ & -3.78 & 0.000 \\
\hline cons & -7.190592 & -22.97 & 0.000 \\
\hline$N$ & & 14,623 & \\
\hline LR chi2 & & 5128.88 & \\
\hline Pseudo R2 & & 0.6205 & \\
\hline & & & \\
\hline$* * * *$ & & & \\
\hline
\end{tabular}

Note: ${ }^{* * *}, * *$ and $*$ respectively mean significant at the level of $1 \%, 5 \%$ and $10 \%$, which are consistent with the following.

As can be seen from TABLE V, at the significance level of $1 \%$, asset risk has a significant impact on whether households enter the stock market. Among them, the index with high asset risk has a significant positive impact on the possibility of households entering the stock market. Household net worth will be a positive impact on the possibility of a family into the stock market, household income will also be a positive impact on its. The higher the level of education, the more likely the family is to enter the stock market. The development differences among different regions in China have gradually disappeared and the development of each region is flat. Household home ownership and the number of family members have negative impacts on stock market participation.

TABLE VI. The regression analysis of asset risk to stock asset ratio

\begin{tabular}{|c|c|c|c|}
\hline holdratio & coefficient & $t$ & $P>t$ \\
\hline risk1 & -.7264236 & $\overline{0} .38$ & 0.702 \\
\hline risk2 & -1.371736 & -1.18 & 0.237 \\
\hline lnincome & .1293399 & 0.36 & 0.716 \\
\hline lnasset & -.1056762 & $\overline{-} .30$ & 0.760 \\
\hline age & .0004249 & 0.03 & 0.974 \\
\hline$e d u$ & -.2088366 & $-\overline{0} 67$ & 0.505 \\
\hline marry & .950807 & 0.75 & 0.454 \\
\hline gender & -.679926 & $-\overline{0}$ & 0.412 \\
\hline east & $\overline{2.287476 * *}$ & $-\overline{2.36}$ & 0.018 \\
\hline west & $-2.152095^{*}$ & 1.88 & 0.060 \\
\hline area & -1.356557 & - & 0.135 \\
\hline estate & .6217303 & 0.40 & 0.686 \\
\hline number & -.145153 & $\overline{-}-52$ & 0.603 \\
\hline cons & 3.270831 & 0.80 & 0.425 \\
\hline$N$ & \multicolumn{3}{|l|}{13,837} \\
\hline LR chi2 & \multicolumn{3}{|c|}{$11.75(0.5480)$} \\
\hline Pseudo R2 & \multicolumn{3}{|l|}{0.0001} \\
\hline
\end{tabular}

As can be seen from TABLE VI, asset risk has no significant impact on the proportion of stock asset investment in household financial assets. At the significant level of 5\%, families in eastern China have a positive and significant impact on the proportion of family stock asset investment. In addition, other variables have no significant impact on the proportion of family stock asset investment.

TABLE VII. Regression analysis of the ratio of asset risk to risky financial assets

\begin{tabular}{|c|c|c|c|}
\hline ratio & coefficient & $\boldsymbol{t}$ & $\boldsymbol{P}>\boldsymbol{t}$ \\
\hline risk1 & $.6615832 * * *$ & 118.07 & 0.000 \\
\hline risk2 & $.0148623 * * *$ & 4.34 & 0.000 \\
\hline lnincome & $.0065511 * * *$ & 6.23 & 0.000 \\
\hline lnasset & $.0142277 * * *$ & 13.91 & 0.000 \\
\hline age & -.0000261 & -0.68 & 0.494 \\
\hline edu & $.007012 * * *$ & 7.59 & 0.000 \\
\hline marry & .0030792 & 0.82 & 0.412 \\
\hline
\end{tabular}




\begin{tabular}{|c|c|c|c|}
\hline gender & -.0008726 & -0.36 & 0.721 \\
\hline east & .004571 & 1.60 & 0.110 \\
\hline west & .0042828 & 1.27 & 0.204 \\
\hline area & -.0016768 & -0.63 & 0.532 \\
\hline estate & $-.0231305^{* * *}$ & -5.09 & 0.000 \\
\hline number & $-.0031968^{* * *}$ & -3.88 & 0.000 \\
\hline cons & $-.2047568^{* * *}$ & -16.91 & 0.000 \\
\hline$N$ & \multicolumn{3}{|c|}{13,837} \\
\hline LR chi2 & 11404.88 \\
\hline Pseudo R2 & \multicolumn{3}{|c|}{-3.7785} \\
\hline
\end{tabular}

As can be seen from TABLE VII, Under the level of $1 \%$, the index of high risk assets has a significant positive impact on the proportion of risky financial assets investment in household financial assets. Under the $1 \%$ significant level, household net worth to risk financial asset investment accounted for the proportion of household financial assets produce positive influence. The development difference among different regions in China has gradually disappeared and the development of each region is flat. The ownership of home by households has a negative impact on the proportion of investment in risky financial assets in household financial assets. The number of family members to risk financial asset investment accounted for the proportion of household financial assets have a negative impact

\section{Conclusion}

The risk of family assets has a significant influence on whether a family participates in the stock market. The index of high asset risk has a significant positive impact on the possibility of households to participate in the stock market; the index of low asset risk has a significant negative impact on the possibility of households to participate in the stock market.

Asset risk has a significant impact on the degree to which households enter the stock market and the risk financial market respectively. Households with risky assets will increase the proportion of stock assets and risky financial assets in total financial assets; households with less risky assets will reduce the proportion of equity assets and risky financial assets in total financial assets.

For the results of the empirical research, the following Suggestions are proposed: First of all, for families, as far as possible to improve the level of education is the most direct way to get in touch with financial knowledge and strengthen asset allocation management. Secondly, for the government, it should pay attention to professional investment education and cultivate mature investment ideas of residents. Attention should be paid to the cultivation of innovative consciousness of financial institutions to provide residents with diversified investment methods and actively promote residents' participation in the financial investment market.

\section{Acknowledgment}

I would first like to thank my advisor, Associate Professor Zhanbing Huang, from the International Business School of Shaanxi Normal University. Whenever I was in trouble or had questions about my research or writing, the professor's office door was always open. He always allowed me to think of it as my own work, but whenever he thought I needed it, he steered me in the right direction.

I would also like to thank the China Household Finance Survey and Research Center of Southwestern University of Finance and Economics for the publicly available data. Without their enthusiastic participation and investment, the confirmatory survey could not have been conducted successfully.

Finally, I would like to thank my parents and friends for their support and continuous encouragement during my years of study and in my research and thesis writing. Without them, this achievement would not have been possible. Thank you very much.

\section{References}

1. Campbell J Y. "Household finance,"Journal of Finance, vol. 61, pp. 1553-1640, 2006.

2. Guiso,Jappelli. "Financial Literacy and Portfolio Diversification,"Working Paper, 2008.

3. Jawad M Addoum. "Household portfolio choice and retirement,"SSRN Working Paper, 2013.

4. Markowitz,H. "Portfolio Selection,”Journal of Finance, vol.7, pp 77-91, 1952 